\title{
Influence of formulation parameters of cement based materials towards gas production under gamma irradiation
}

\author{
D. Chartier ${ }^{1 *}$, J.Sanchez-Canet ${ }^{1}$, L. Bessette ${ }^{2}$, S. Esnouf ${ }^{3}$, J-P. Renault ${ }^{4}$ \\ ${ }^{1}$ CEA, DEN, Univ Montpellier, DE2D, SEAD, F-30207 Bagnols-sur-Cèze, France. \\ 2 Vicat, 4, Rue Aristide Bergès, F-38080 L'Isle d'Abeau, France \\ ${ }^{3}$ CEA, DEN, DPC, SECR, F-91191, Gif-sur-Yvette, France. \\ ${ }^{4}$ CEA, DRF/NIMBE 331 CNRS, F-91191, Gif-sur-Yvette, France \\ "Main Author , E-mail: david.chartier@cea.fr
}

Keywords: radiolysis, gamma irradiation, hydrogen, cement, Portland, sulfo-aluminate, waste, conditioning

\begin{abstract}
The release of radiolysis gas is a concern that may restrict the use of cement materials to condition intermediate level radioactive waste. Indeed, water naturally present in cement materials produces hydrogen gas (which can be explosive/flammable under some conditions) when it is exposed to ionizing radiation.
\end{abstract}

The primary goal of the MATRICE (MAterials Resistant to Irradiation based on Cement) project is to identify and define formulations of cement materials in order to minimize the quantities of hydrogen gas released by radiolysis. The first approach is the minimization of water amount in standard Portland materials (calcium silicate-based cements) by addition of specific compounds (superplasticizers) to enable the preparation of wasteform. The second approach is to use "alternative" cement such as calcium sulfoaluminate cement. This cement was expected to release less hydrogen because the quantity of water needed for cement hydration is higher than Portland and moreover, their hydrates differ from those of hydrated calcium silicate mostly encountered in Portland based materials.

Based on gamma irradiations with a ${ }^{60} \mathrm{Co}$ source, the results obtained demonstrate that the first approach is efficient but yet limited because the production of hydrogen of Portland pastes is about proportional to the total amount of water present in the materials. Thus, a tremendous drop of hydrogen production cannot be reach because rheological constraint does not allow a huge reduction of water, even with efficient superplasticizers. The second approach using calcium sulfoaluminate cements as an alternative binder provides results that are quite similar to Portland cement concerning the production of hydrogen under gamma irradiation. 


\section{Introduction}

The decommissioning of nuclear facilities in the coming decades will generate various types of waste (metals, sludge, aqueous solutions, ions exchange resins...). Conditioning radioactive waste via solidification in a cement material is a robust solution, which is already widely used for decades [1]. This solution corresponds to a technical economic optimum for a wide range of waste. However, for storage and/or disposal safety reasons, its use can be restricted by the amount of radioactivity. Indeed, water naturally present in cement matrices produces hydrogen gas (which can be explosive/flammable under some conditions) when it is exposed to ionizing radiations emitted by waste [2]. Moreover, over pressurization of cement materials by radiolysis gas can lead to its disaggregation in specific condition (materials under water) as demonstrated by Kertesz [3] and Madic [4]. Optimized cement matrices therefore need to be formulated to limit the release of radiolytic gas to an acceptable level in order to facilitate the conditioning of radioactive waste. The first approach of the present work is the minimization of water amount of Portland based materials (calcium silicate-based cements) by addition of specific compounds based on soluble polymers (superplasticizers) to enable the preparation of wasteform. Indeed, a strong reduction of water in concrete or mortar formulations makes them difficult to prepare (mixing) and to use (casting, injection, pumping) without superplasticizers. The second approach is to use "alternative" cements such as calcium sulfoaluminate cement (CSA) for example. This kind of cement was expected to release less hydrogen under irradiation because of its higher chemical water demand than Portland [5] and/or the nature of its hydrates that differ from those of hydrated calcium silicate encountered in Portland based materials. Indeed, it is sometimes assumed that water present in the porosity of cement materials is more likely to produce hydrogen under irradiation than water of cement hydrates [6, 7]. Thus, cement with high chemical water demand compared to Portland is expected to produce less hydrogen under irradiation.

In the present work, cement materials are assessed by external gamma irradiation to quantify the amount of gas released by radiolysis. The effect of such gamma irradiation on other properties (microstructure, mechanical strength...) is ongoing and will be published later. Nevertheless, available data based on XRD show that gamma and electron irradiations do not alter the structure of Portland hydrates up to $300 \mathrm{MGy}$ [8]: neither amorphization nor appearance of new phases occurs. Same results were obtained on aluminum hydroxide [9] that are encountered in CSA and calcium aluminate cements. Considering mechanical strength, some authors measured moderate decreases of compressive strength of Portland concrete or mortars after gamma irradiation at doses of $500 \mathrm{kGy}$ 
[10] or $260 \mathrm{kGy}$ [11]. These results are surprising, since according to [12] it is assumed that the dosage limit for deterioration of mechanical properties of concrete is larger than $100 \mathrm{MGy}$. The effect of irradiation on concrete is also a concern considering the durability of concrete structures of nuclear power plants [13]. An international forum for collaboration has been created in 2015 to deal with this subject (The International Committee on Irradiated Concrete (ICIC) [13, 14]). Nevertheless, in the case of nuclear power plant, neutron irradiation is sometimes predominant which is not the case for cemented nuclear waste.

\section{Experimental}

Cement materials (cement pastes or mortars) were prepared at laboratory scale (about $200 \mathrm{~mL}$ ). All components were weighted and vigorously mixed in a mechanical blade stirrer (Heidolph RZR 2102 control) during five minutes before being cast in $15 \mathrm{~mL}$ plastic tubes (centrifugation tubes "SuperClear" provided by VWR). Typical samples are small cylinders (diam. $15 \mathrm{~mm}$ ) of $10 \mathrm{~mL}$ of cement materials. Plastic tubes were immediately sealed with their caps after filling to avoid desiccation of cement materials, especially during hydration of cement. Samples were then stored during three months minimum in their airtight plastic tubes before irradiation to allow the cement hydration to complete. Before irradiation, samples were demolded and then placed in glass tubes of $105 \mathrm{~mL}$, deaerated (3 cycles of depressurization at $30 \mathrm{hPa}$ and pressurization with argon) that were flame sealed under $900 \mathrm{hPa}$ of pure argon (Alphagaz 1 of Air Liquide). Samples were weighted to control a possible desiccation during storage and sealing. Typical desiccation was always less than $1 \%$ of total water of cement material tested.

Gamma irradiations $\left({ }^{60} \mathrm{Co}\right)$ where performed with the experimental irradiator Gammatec located in Marcoule, France. Dose rate comprised between 200 and 1100 (the mean value $900 \mathrm{~Gy} \cdot \mathrm{h}^{-1}$ was further used) were used to achieve total doses of 150, 300 and 500 kGy. Dosimetry was estimated using Perspex dosimeter supplied by Harwell [15] and used according to [16]. The temperature was regulated between 20 and $25^{\circ} \mathrm{C}$ during irradiation. Calculations performed with PENELOPE (v.2001) software [17] show that the dose deposited by a ${ }^{60} \mathrm{Co}$ source in a typical Portland cement material (density $2.2 \mathrm{~g} \cdot \mathrm{cm}^{3}$ containing $9 \%$ mass of water and $47 \%$ mass of $\mathrm{SiO}_{2}$ sand) is about $-13 \%$ lower than the dose deposited in water (i.e. the dose given by Perspex dosimeter). Nevertheless, considering possible variations of this correction (cement materials tested in this work have been prepared with different formulations) it was decided to use uncorrected values of doses to calculate yields of gas production thereafter. 
After irradiation, the gas of sealed glass tubes were analyzed using à Varian CP 3800 model gas chromatography with Galaxie software. $\mathrm{H}_{2}$ but also $\mathrm{O}_{2}, \mathrm{~N}_{2}$ and $\mathrm{CH}_{4}$ were quantified using standards. Nitrogen allows us to quantify the amount of residual air in the ampoules after sealing. When needed, comprehensive gas analyses were performed with either a high resolution gas mass spectrometer with direct inlet (Thermo Fischer Scientific MAT-271) or a quantitative gas mass spectrometer designed and built at the CEA [18].

The quantifications of gas were made considering the percentage of gas thus determined $\%_{v o l}$, the gas pressure in the tubes after irradiation $P_{f}$ and the free volume of the glass tubes $V_{\text {free }}$ :

$$
n(\text { gas })=\frac{P_{f} \cdot \%_{\text {vol }} \cdot V_{\text {free }}}{R \cdot T}
$$

where $R$ is the gas constant and $T$ the sample's temperature.

Radiolysis results are usually expressed as radiolysis gas yields ( $G$, in $\mathrm{mol} / \mathrm{J}$ ):

$$
G(\text { gas })_{\text {material }}=\frac{n(\text { gas })}{D \cdot m}
$$

where $\mathrm{n}$ is the amount of the gas measured (in mole), $\mathrm{D}$ the absorbed dose of gamma radiation in the sample (in Gray) and $\mathrm{m}$ the mass of irradiated sample (in $\mathrm{kg}$ ). As mixing $\mathrm{H}_{2} \mathrm{O}$ is the only significant source of hydrogen in the cement materials (water brought by gypsum being negligible), the radiolysis yields of $\mathrm{H}_{2}$ can also be expressed considering the total mass of water present in the material.

$$
\frac{n\left(H_{2}\right)}{D \cdot m_{\text {total water }}}=\frac{G\left(H_{2}\right)_{\text {material }}}{w_{\text {water }}}
$$

Where $w_{\text {water }}$ is the mass fraction of total water of the material.

This radiolytic yield is convenient to compare the production of hydrogen of materials containing different amounts of water.

Cements were provided by Vicat and Calcia and used as received. Limestone filler Betocarb HP (quarry of Sassenage) was provided by Omya whereas siliceous filler Sikron E600 (quarry of Entraigues) was provided by Sibelco. Superplasticizers (MasterRheobuild 1000, Pozzolith 400N and MasterEase 3000) were provided by BASF and used as received. Low calcium Flying ashes were provided by EdF (coal-fueled power plant of Cordemais, France) and E.ON (coal-fueled power plant of Carling, France). CaMoO4 (99.8\% ref. 41865) and $\mathrm{Na}_{2} \mathrm{MoO}_{4}, 2 \mathrm{H}_{2} \mathrm{O}$ (98\% ref. A19222) were provided by Alpha Aesar. $\mathrm{NaNO}_{3}$ (99.5\% ref. 27955) and $\mathrm{NaNO}_{2}$ (98\% ref. 27959) were provided by VWR. 


\section{Irradiation of Portland cement based materials}

\subsection{Preliminary experiments}

We first checked that the production of $\mathrm{H}_{2}$ of cement pastes is proportional to the dose in the range of 150 to $500 \mathrm{kGy}$, so that it is possible to determine radiolytic yields as the slope of the gas productions versus the dose plot (Figure 1 ): $\mathrm{G}\left(\mathrm{H}_{2}\right)_{\text {material }}=(1,0 \pm 0,1) \cdot 10^{-8} \mathrm{~mol} / \mathrm{J}$.

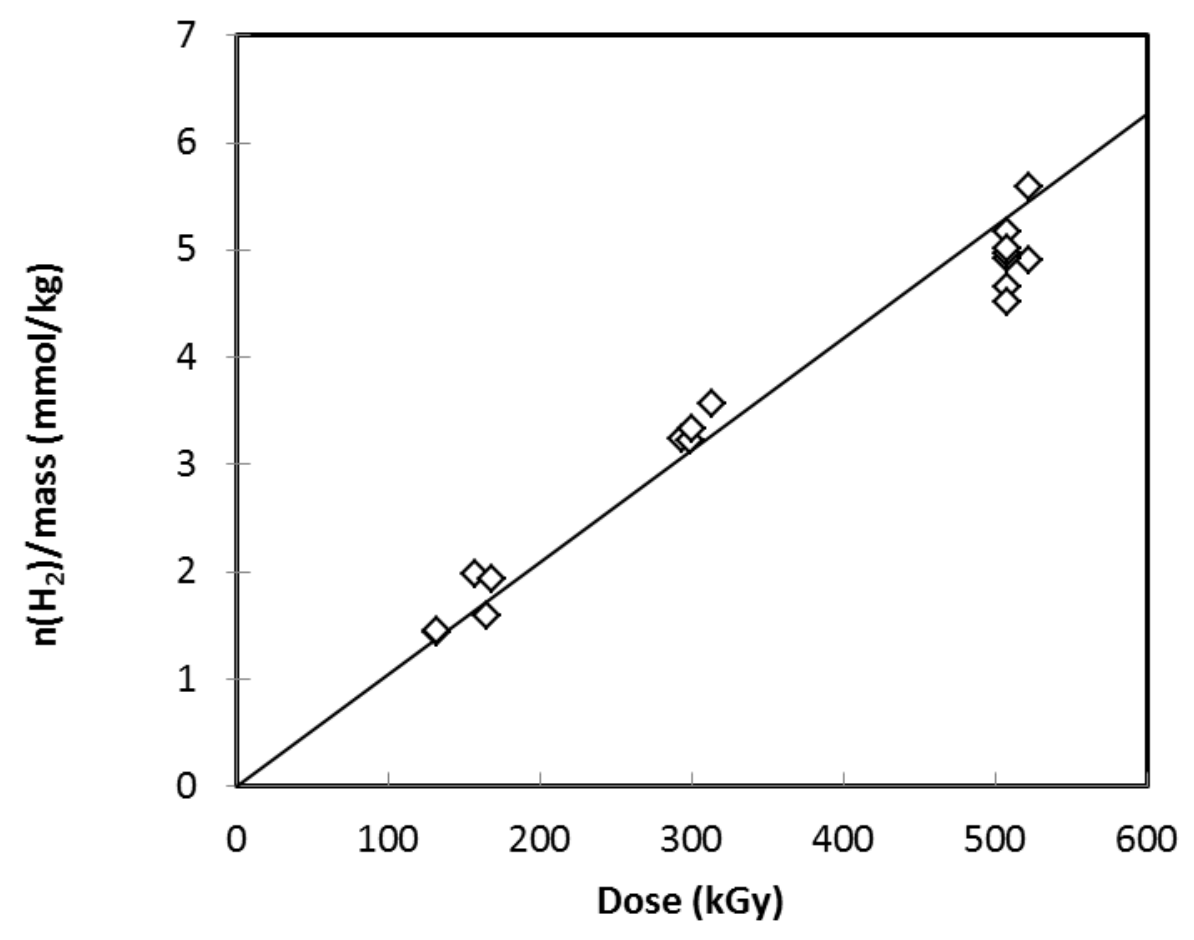

Figure 1. Production of $\mathrm{H}_{2}$ as a function of the dose on $10 \mathrm{~mL}$ cylindrical samples of Portland Ultimat Pastes under gamma irradiation. Water/Cement $=0.4$.

It has also been checked that firstly no significant amount of $\mathrm{H}_{2}$ remains trapped within the porosity of the material and secondly gas transport does not influence $\mathrm{H}_{2}$ release by studying the influence of fragmentation of the samples. No significant differences in $\mathrm{H}_{2}$ production were detected whether the sample is in one piece ( $10 \mathrm{~mL}$ cylinder), broken in centimeter pieces or more finely grinded (Table 1$)$. 
Table 1. Influence of the fragmentation of $10 \mathrm{~mL}$ cylindrical samples on radiolytic hydrogen yields of Portland Ultimat Pastes. Water/Cement $=0.4$. Dose $500 \mathrm{kGy}$ at $900 \mathrm{~Gy} \cdot \mathrm{h}^{-1}$.

\begin{tabular}{|c|c|}
\hline State of sample & $\mathrm{G}\left(\mathrm{H}_{2}\right)$ material $(\mathrm{mol} / \mathrm{J})$ \\
\hline Monolithic (4 samples) & $(1.0 \pm 0.1) \cdot 10^{-8}$ \\
\hline Broken (particle about $1 \mathrm{~cm})$ & $(9.8 \pm 1.0) \cdot 10^{-9}$ \\
\hline Broken (particle about $1 \mathrm{~cm}$ ) duplicate & $(9.9 \pm 1.0) \cdot 10^{-9}$ \\
\hline Grinded (particles $<100 \mu \mathrm{m})$ & $(9.1 \pm 1.0) \cdot 10^{-9}$ \\
\hline Grinded (particles $<100 \mu \mathrm{m})$ duplicate & $(8.9 \pm 1.0) \cdot 10^{-9}$ \\
\hline
\end{tabular}

\subsection{Effect of water content on different Portland cements}

Three different calcium silicate Portland cement have been tested, covering a large range of composition for such cement (Table 2):

- a $\mathrm{C}_{3} \mathrm{~A}$ free Portland ( $\mathrm{SRO}$ ) containing also few $\mathrm{SO}_{3}, \mathrm{Na}$ and $\mathrm{K}$ (named "Ultimat") provided by Vicat

- an ordinary Portland provided by Calcia containing both $C_{3} A$ and $C_{4} A F$

- a white Portland cement containing very little amount of iron (and thus very little $\mathrm{C}_{4} \mathrm{AF}$ phase) and very low impurities such as $\mathrm{Mg}, \mathrm{Mn}, \mathrm{Ti}, \mathrm{K}$ and $\mathrm{Na}$

During hydration, all those Portland cement produce mainly calcium silicate hydrates (C-S-H) and Portlandite $(\mathrm{CH})$ and also few ettringite $\left(\mathrm{C}_{3} \mathrm{~A} .3 \mathrm{C} \$ \mathrm{H}_{32}\right)$ and calcium aluminate monosulfate $\left(C_{3}\right.$ A.C $\left.\$ . H_{12}\right)$. Chemically bound water in Portland cement hydrates is about 22 to $25 \mathrm{wt} \% /$ cement. Nevertheless, total hydration of Portland cement paste requires more water, about $42 \mathrm{wt} \% /$ cement, because of water trapped within the nanoporosity of C-S-H gel [19].

The significant difference in clinker composition (Table 2) between quantification by XRD measurement and estimates with Bogue's formula is mainly related to potential intrinsic biases of Bogue calculations. The biases originate primarily from the compositional variation in phase solid, resulting in deviation from that assumed in the calculations [20]. 
Table 2 Compositions of the three Portland cement tested according to supplier's data (\%mass). *quantification by XRD (Rietveld refinement) in the case of Portland Ultimat (Bogue formula otherwise).

\begin{tabular}{|c|c|c|c|}
\hline & $\begin{array}{l}\text { Portland Ultimat CEM I } \\
52,5 \mathrm{~N} \text { SR0 (free of } \mathrm{C}_{3} \mathrm{~A} \text { ) } \\
\text { provided by Vicat (St } \\
\text { Egreve plant) }\end{array}$ & $\begin{array}{l}\text { Ordinary Portland } \\
\text { provided by Calcia } \\
\text { (Couvrot plant) }\end{array}$ & $\begin{array}{l}\text { White Portland provided } \\
\text { by Calcia (Cruas plant) }\end{array}$ \\
\hline $\begin{array}{c}\text { Elemental } \\
\text { composition of } \\
\text { clinker (\%mass) }\end{array}$ & $\begin{array}{c}\mathrm{SiO}_{2}: 20.91 ; \mathrm{Al}_{2} \mathrm{O}_{3}: 3.51 ; \\
\mathrm{Fe}_{2} \mathrm{O}_{3}: 6.51 ; \mathrm{TiO}_{2}: 0.20 \\
\mathrm{MnO}: 0.06 ; \mathrm{CaO}^{2} \text { 64.91; } \\
\mathrm{MgO}: 0.81 ; \mathrm{SO}_{3}: 1.52 ; \\
\mathrm{K}_{2} \mathrm{O}: 0.57 ; \mathrm{Na}_{2} \mathrm{O}: 0,09 ; \\
\mathrm{P}_{2} \mathrm{O}_{5}: 0.20 ; \mathrm{S}^{2-}: 0 ; \mathrm{Cl}^{-} \\
: 0.03\end{array}$ & $\begin{array}{c}\mathrm{SiO}_{2}: 19.6 ; \mathrm{Al}_{2} \mathrm{O}_{3}: 5.2 \\
\mathrm{Fe}_{2} \mathrm{O}_{3}: 2.3 ; \mathrm{TiO}_{2}: 0.3 \\
\mathrm{MnO}: 0 ; \mathrm{CaO}^{2}: 65 ; \\
\mathrm{MgO}: 1 ; \mathrm{SO}_{3}: 3.5 ; \\
\mathrm{K}_{2} \mathrm{O}: 1.09 ; \mathrm{Na}_{2} \mathrm{O}: 0.06 \\
\mathrm{P}_{2} \mathrm{O}_{5}: 0.2 ; \mathrm{S}^{2-}: 0.02 ; \mathrm{Cl}^{-} \\
: 0.02\end{array}$ & $\begin{array}{c}\mathrm{SiO}_{2}: 22.1 ; \mathrm{Al}_{2} \mathrm{O}_{3}: 4.2 \\
\mathrm{Fe}_{2} \mathrm{O}_{3}: 0.3 ; \mathrm{TiO}_{2}: 0.2 ; \\
\mathrm{MnO}: 0 ; \mathrm{CaO}: 66.9 ; \\
\mathrm{MgO}: 0.7 ; \mathrm{SO}_{3}: 2.7 \\
\mathrm{~K} 2 \mathrm{O}: 0.1 ; \mathrm{Na}_{2} \mathrm{O}: 0 ; \\
\mathrm{P}_{2} \mathrm{O}_{5}: 0.1 ; \mathrm{S}^{2-}<0.02 ; \mathrm{Cl}^{-} \\
<0.007\end{array}$ \\
\hline $\begin{array}{l}\mathrm{C}_{3} \mathrm{~S} \text { (\%mass in } \\
\quad \text { clinker) }\end{array}$ & $65.1\left(59^{*}\right)$ & 67 & 73 \\
\hline $\begin{array}{l}\mathrm{C}_{2} \mathrm{~S} \text { (\%mass in } \\
\quad \text { clinker) }\end{array}$ & $10.2\left(22^{*}\right)$ & 12 & 13 \\
\hline $\begin{array}{c}\mathrm{C}_{3} \mathrm{~A} \text { (\%mass in } \\
\text { clinker) }\end{array}$ & $0\left(0^{*}\right)$ & 11 & 12 \\
\hline $\begin{array}{c}\mathrm{C}_{4} \mathrm{AF} \text { (\%mass in } \\
\text { clinker) }\end{array}$ & $19.8\left(17^{\star}\right)$ & 7 & 1 \\
\hline $\begin{array}{l}\text { Addition of } \\
\text { limestone }\end{array}$ & $0 \%$ mass ( $100 \%$ clinker) & $2 \%$ mass ( $98 \%$ clinker) & $2 \%$ mass (98\% clinker) \\
\hline gypsum & $0 \%$ & $\begin{array}{c}5.5 \\
\text { \%mass/(clinker+limesto } \\
\text { ne) }\end{array}$ & $\begin{array}{c}6 \\
\text { \%mass/(clinker+limeston } \\
\text { e) }\end{array}$ \\
\hline
\end{tabular}

Cement pastes have been prepared with those three cements using water/cement ratios of $0.2,0.3$, $0.4,0.5$ and 0.6. Those ratios cover the range used to prepare concretes or mortars and are thus representative of cement materials. 
After irradiation of those cements pastes, only hydrogen can be attributed unambiguously to radiolysis processes in the gas of sealed tubes. The variation of the yields of hydrogen production as a function of the initial amount of water used to prepare the materials is presented in Figure 2 for each cement. The mass fractions of water of materials are known from their preparation (i.e. a cement paste of water/cement ratio of 0.4 contains $28.6 \%$ mass of water) knowing that samples are preserved from desiccation during hydration and also during irradiation.

For comparison, the expected contribution of water to $\mathrm{H}_{2}$ production is given by Equation 1 considering that all water (free water and water of cement hydrates) produces hydrogen with the yield of bulk water and that the dose absorbed by water is the one determined by dosimetry:

\section{$G\left(H_{2}\right)_{\text {matérial }}=G\left(H_{2}\right)_{\text {water }} \times$ mass fraction of total water of materials Equation 1}

where $G\left(\mathrm{H}_{2}\right)_{\text {water }}$ is the primary yield of bulk water measured under gamma irradiation in the presence of scavengers of $\mathrm{HO}^{\circ}$ or $\mathrm{O}^{\circ-}$ radicals like $\mathrm{Br}^{-}$ions $(\mathrm{NaBr}[21]$ or $\mathrm{KBr}[22]): \mathrm{G}\left(\mathrm{H}_{2}\right)_{\text {water }}=4.4 .10^{-8}$ $\mathrm{mol} / \mathrm{J}$.

According to Figure 2a, $G\left(\mathrm{H}_{2}\right)_{\text {matérial }}$ of Portland pastes are almost proportional to the fraction of total water in the cement pastes. Hydrogen production of white Portland is significantly higher than others and very close to the Equation 1. It is noteworthy that linear relationships between the yield and the mass fraction of water are suitable for low and high water/cement ratios where the status of water is noticeably different $[19,23]$ : for water/cement ratios less or equal to 0.3 , the major part of water is chemically bound in the hydrates (C-S-H or CH mostly) whereas free water is noticeably present in the porosity of cement paste of water/cement superior to 0.5 because of its excess towards the chemical demand of cement [19]. This means first that the yield of production of $\mathrm{H}_{2}$ by water dimly depends on the status of water in Portland cement based materials. This is evidenced by converting $\mathrm{G}\left(\mathrm{H}_{2}\right)_{\text {materials }}$ of Figure 2a into $\mathrm{G}\left(\mathrm{H}_{2}\right)_{\text {materials }}$ /(mass fraction of water) (Figure 2b), i.e. the yield calculated considering only the mass of water (see experimental part): except for the white Portland cement, $\mathrm{H}_{2}$ yields are rather stable in the range of water/cement ratios tested (from 16.6 to 37.5\%mass. of water). The yields of the white Portland even increase for the lower water, which means that the water bound to hydrates is more sensitive to radiolysis than bulk water in this case.

The fact that $\mathrm{G}\left(\mathrm{H}_{2}\right)_{\text {total water }}$ of Portland materials are close to the primary yield of bulk water means that the $\mathrm{H}_{2}$ produced in cement is not much sensitive to oxidative radiolytic species $\mathrm{HO}^{\circ}$ or $\mathrm{O}^{\circ}$. Indeed, the primary yield of bulk water has to be measured in the presence of scavengers of $\mathrm{HO}^{\circ}$ or $\mathrm{O}^{\circ-}$ radicals like $\mathrm{Br}^{-}$ions ( $\mathrm{NaBr}[21]$ or $\mathrm{KBr}$ [22]) to protect $\mathrm{H}_{2}$ form their attack. Here, we observe $\mathrm{H}_{2}$ 
without such scavenger, and thus, we can assume that the Portland cement material itself act as a $\mathrm{HO}^{\circ} . \mathrm{O}^{\circ-}$ scavenger.

Considering the results in relation to the three different Portland tested, it is clear that the white Portland releases significantly more $\mathrm{H}_{2}$ than the ordinary Portland and the "free $\mathrm{C}_{3} \mathrm{~A}$ " Portland, the two latter being not markedly different. The higher production of the white Portland might be related to its low impurities content compared to the other Portland. Nevertheless, considering the effect of addition of $\mathrm{FeOOH}$ on Portland cement which increases the production of $\mathrm{H}_{2}$ under gamma irradiation [24], the low amount of iron typical of white Portland cement cannot explain its higher production of $\mathrm{H}_{2}$ than other Portland cements. Furthermore, the low amount of calcium carbonate (see Table 2) added in the white and ordinary Portland cements seems to have no significant influence on $\mathrm{H}_{2}$ production compared to the "free $\mathrm{C}_{3} \mathrm{~A}$ " Portland which is free of calcium carbonate addition. The neutrality of calcium carbonate towards $\mathrm{H}_{2}$ production is confirmed further in the present work by the study of the effect of various fillers (see Table 3 ). 
Figure 2a
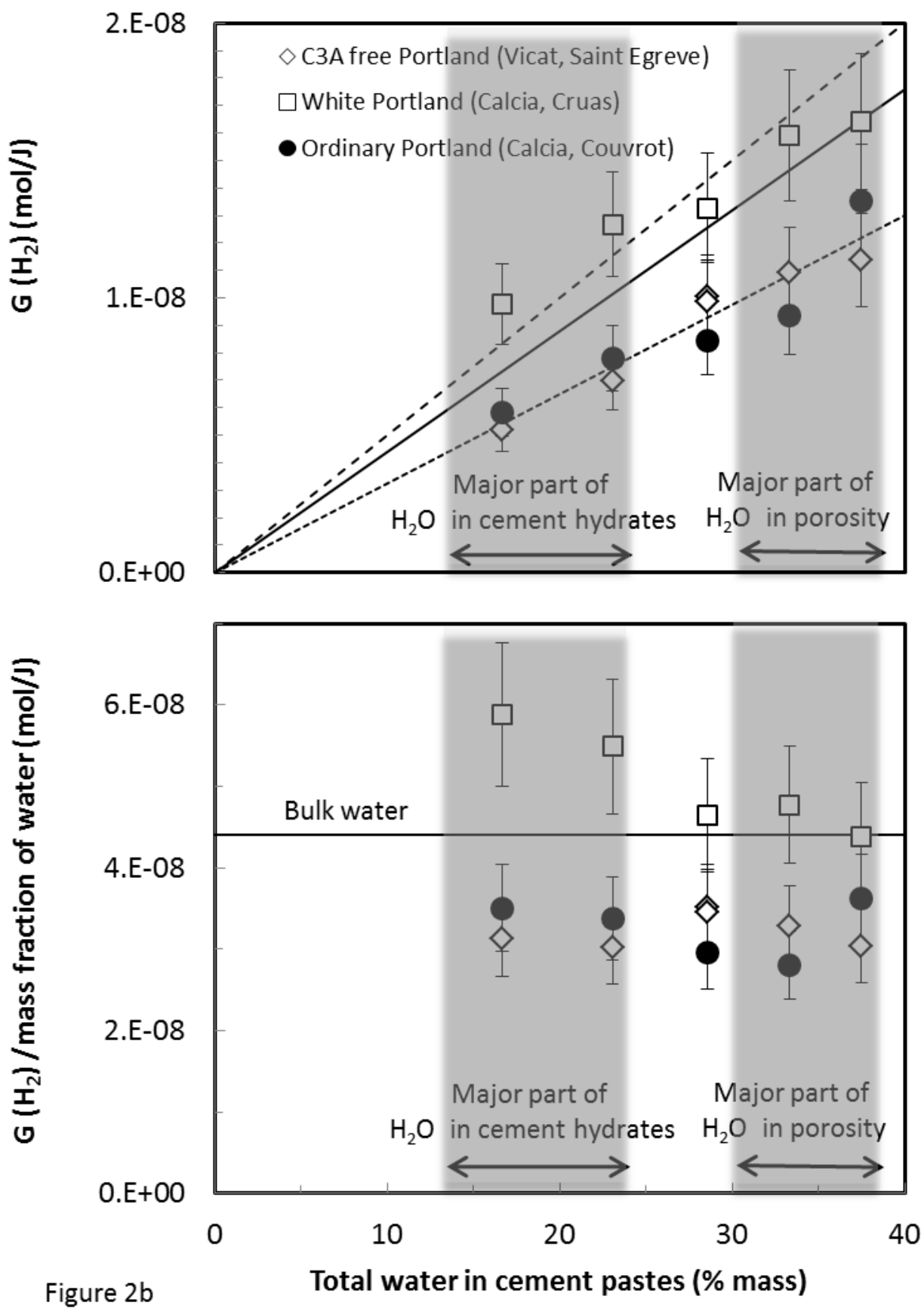

Figure 2. Radiolytic hydrogen yields of Portland cement pastes as a function of the total amount of water. Absorbed dose of $500 \mathrm{kGy}$ at $900 \mathrm{~Gy} \cdot \mathrm{h}^{-1}$. (Figure 2a: radiolytic yields of materials; Figure $2 \mathrm{~b}$ : radiolytic yields normalized with regard to the amount of water of materials). Uninterrupted line of Figure 2a: yield according to Equation1. Dashed lines of Figure 2a: linear regression for each cement.

According to these results, it is possible to reduce the hydrogen production of Portland based materials by reducing the amount of water in formulations of mortars and concretes because the production is proportional to the quantity of total water. Nevertheless, this approach is limited to a 
reduction of about a factor 2 because rheological constraints encountered during the mixing process of fresh mortar or concrete do not allow a huge reduction of water in practice.

\subsection{Effect of mineral additions}

As the production of $\mathrm{H}_{2}$ of Portland pastes tested is on the all, proportional to the amount of total water, it was also of interest to check this on mortars containing various amounts of sand. This has been done with the free $\mathrm{C}_{3} \mathrm{~A}$ Portland (SRO). Simple mortars (mix of sand, cement and water, with no additive) with water/cement ratio of 0.4 where prepared with various amount of siliceous sand (sand/cement from 0 to 3). The results presented Figure 3 suggest that the radiolytic yields of hydrogen of such simple Portland mortars is also proportional to the amount of total water and thus can also be predicted by Equation 1 .

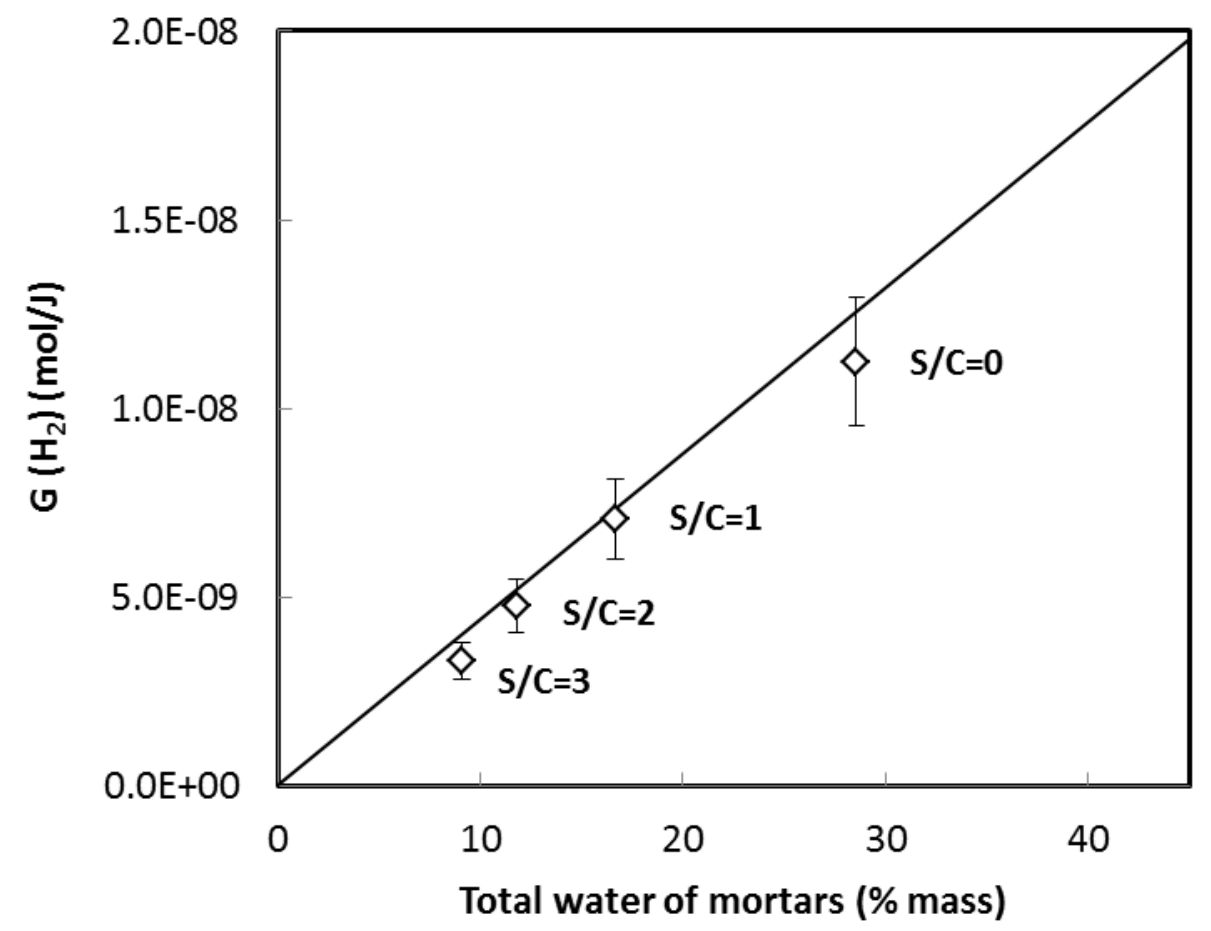

Figure 3. Radiolytic hydrogen yields of Portland cement mortars (water/cement $=0.4$, variable sand/cement ratio from 0 to 3 ) as a function of the total amount of total water. Absorbed dose of 150 and 300 kGy at 800 Gy.h ${ }^{-1}$. Uninterrupted line: yield according to Equation1.

Other mineral products commonly used in cement materials (flying ashes, calcium carbonate or siliceous fillers) were also tested for their possible effect on the production of hydrogen under gamma irradiation. To study this point, cement pastes of the "free $\mathrm{C}_{3} \mathrm{~A}$ " Portland cement SRO have been prepared with or without such mineral addition. In this case, the mass ratio addition/cement $=1 / 3$ and the water $/($ cement + addition $)=0.4$ so that the total amount of water is 
equal to $28.6 \%$ mass for all materials. The results of gamma irradiation of such materials are presented Table 3. Considering the variability of results, it can be concluded that the mineral additions tested have no significant influence on the production of hydrogen. Thus, the radiolytic yield of $\mathrm{H}_{2}$ for such materials can still be estimated with Equation 1.

Table 3. Influence of mineral additions on radiolytic yields of $\mathrm{H}_{2}$ of $\mathrm{C}_{3} \mathrm{~A}$ free Portland (Ultimat) cement pastes. Absorbed doses of 150 or $300 \mathrm{kGy}$ and rate dose of 200 or $900 \mathrm{~Gy} \cdot \mathrm{h}^{-1}$. water $/($ cement + addition $)=0.4$.

\begin{tabular}{|c|c|}
\hline Without mineral additive & $\mathrm{G}\left(\mathrm{H}_{2}\right)$ materials (mol/J) \\
\hline With flying ashes (Carling) & $\begin{array}{c}(1.1 \pm 0.1) \cdot 10^{-8} \\
\text { (average of 7 measurements on distinct samples) }\end{array}$ \\
\hline With flying ashes (Cordemais) & $\begin{array}{c}(1.2 \pm 0.2) .10^{-8} \\
\text { (average of 7 measurements on distinct samples) }\end{array}$ \\
\hline With CaCO filler (Betocarb HP Sassenage) $^{(1.2 \pm 0.2) .10^{-8}}$ \\
(average of 6 measurements on distinct samples) \\
\hline With $\mathrm{SiO}_{2}$ filler (Sikron E600) & $\begin{array}{r}(1.1 \pm 0.3) .10^{-8} \\
\text { (average of 6 measurements on distinct samples) }\end{array}$ \\
\hline & $\begin{array}{r}(1.2 \pm 0.3) .10^{-8} \\
\text { (average of 7 measurements on distinct samples) }\end{array}$ \\
\hline
\end{tabular}

\subsection{Effect of superplasticizers}

As demonstrated previously, one way to reduce the radiolytic hydrogen production of Portland based material is to reduce its global amount of water. Nevertheless, it is well known that a reduction of water degrades the workability of fresh mortars or concretes and can be a serious issue to prepare homogeneous and compact materials. To counterbalance this deleterious effect of water reduction on concrete workability, superplasticizers (SP) based on soluble polymers are widely used for decades. As these products are hydrogenated polymers, it is of interest to test their influence on cement pastes under irradiation. Experiments were performed with three superplasticizers provided by BASF: $1^{\circ}$ ) MasterRheobuild 1000 which is based on calcium polynaphtalenes sulfonates, $2^{\circ}$ )

Pozzolith 400N which is based on sodium polynaphtalenes sulfonates and $3^{\circ}$ ) MasterEase 3000 which is based on Poly Aryl Ether (patent EP 2886580 A1). So as to avoid instability and segregation of cement pastes in the presence of superplasticizers, water/cement ratios of cement pastes have been set to 0.3. The tested Portland cement is the SRO type produced by Vicat. Dosages of SP have been set to obtain fluid but stable pastes and are thus different for each SP: $0.8 \%$ mass of dry 
matter/cement for Pozzolith400N, 0.056\% mass of dry matter/cement for MasterEase 3000, $0.395 \%$ mass of dry matter/cement for MasterRheobuild 1000. Results of gamma irradiations presented Figure 4 show that there is no major influence of SP on the production of hydrogen of Portland cement pastes. There might be a sight effect of MasterRheobuild 3000 that could slightly increase the hydrogen production but this effect should be confirmed by other measurements. Indeed, no such effect of MasterRheobuild 3000 has been evidenced with sulfo-aluminate cement (see further Figure 6).

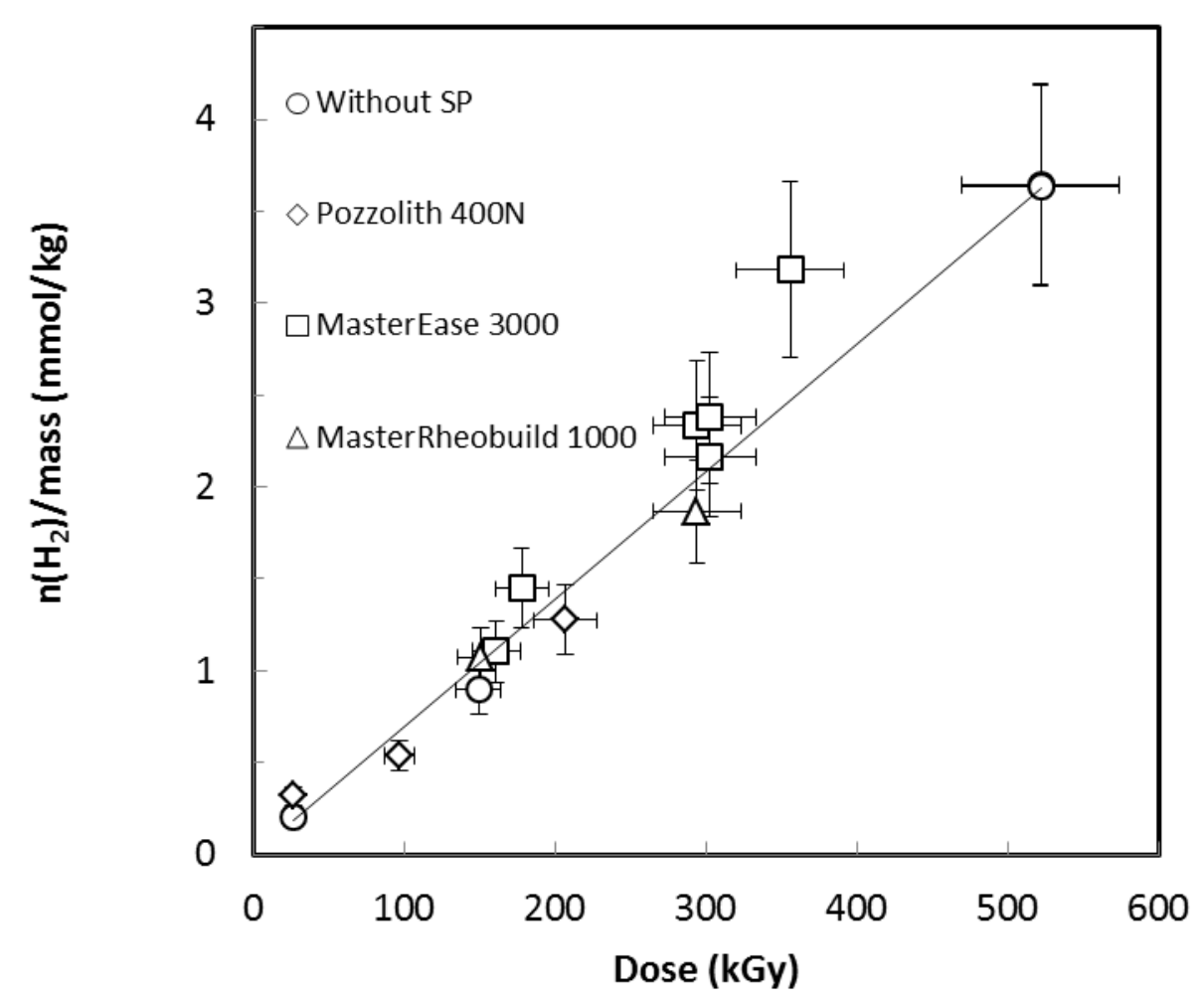

Figure 4. Influence of various superplasticizer on radiolytic $\mathrm{H}_{2}$ production of Ultimat SRO cement pastes (water/cement= 0.3). Dose rate of $900 \mathrm{~Gy} \cdot \mathrm{h}^{-1}$. 


\subsection{Effect of reductive species scavengers $\mathrm{Na}_{2} \mathrm{MoO}_{4}, \mathrm{NaNO}_{3}, \mathrm{NaNO}_{2}$}

In order to reduce the production of hydrogen of Portland based materials it is conceivable to add products known to lower this production in aqueous media under irradiation such as sodium nitrate, sodium nitrite and sodium molybdenum [22]. These products named "scavengers" in the field of radiolysis science, are supposed to react with radiolytic precursors of $\mathrm{H}_{2}$ such as solvated or presolvated electron. Thus, cement pastes of Portland Ultimat have been prepared with $\mathrm{NaNO}_{3}$ (2\%mass $\mathrm{NO}_{3}{ }^{-} /$cement) or $\mathrm{NaNO}_{2}\left(2 \%\right.$ mass $\mathrm{NO}_{2}{ }_{2}$ /cement) or $\mathrm{Na}_{2} \mathrm{MoO}_{4}, 2 \mathrm{H}_{2} \mathrm{O}\left(2 \%\right.$ mass $\mathrm{MoO}_{4}{ }^{2-}$ /cement) dissolved in the mixing water (water/cement $=0.4$ ). The low amounts of such products towards cement have been selected to avoid a strong disturbance of cement hydration that could make it unusable as a binder.

After irradiation the cement pastes containing sodium molybdate displayed a slight but hardly significant drop of $\mathrm{H}_{2}$ production as presented in Table 4. With the same $\mathrm{Na}_{2} \mathrm{MoO}_{4} / \mathrm{H}_{2} \mathrm{O}$ ratio of 0.062 $\left(\left[\mathrm{MoO}_{4}\right]=0.3 \mathrm{~mol}^{-\mathrm{L}^{-1}}\right)$, the drop of $\mathrm{H}_{2}$ production is more significant in bulk water (about a factor 2 ) according to [22] than in cement (-19\%). The poor efficiency of sodium molybdate in calcium silicate based materials such as Portland may be explained by the precipitation of molybdate into very stable $\mathrm{CaMoO}_{4}$ (powellite) by calcium ions released in water during hydration of Portland cement. This phenomenon of precipitation has already clearly been evidenced in a study dealing with the conditioning of molybdate waste in Portland cement [25]. Moreover addition of powellite in Portland paste (3\%mass of $\mathrm{CaMoO}_{4} /$ cement) has no significant effect on radiolytic $\mathrm{H}_{2}$ production (Table 4).

Table 4. Influence of $\mathrm{Na}_{2} \mathrm{MoO}_{4}$ and $\mathrm{CaMoO}_{4}$ on radiolytic yields of $\mathrm{H}_{2}$ of $\mathrm{C}_{3} \mathrm{~A}$ free Portland (Ultimat) cement pastes. Absorbed doses of 150 or $300 \mathrm{kGy}$ and rate dose of 200 or $900 \mathrm{~Gy} \cdot \mathrm{h}^{-1} .2 \%$ mass $\mathrm{MoO}_{4}{ }^{2-} / \mathrm{cement}$.

\begin{tabular}{|c|c|}
\hline & $\mathrm{G}\left(\mathrm{H}_{2}\right)$ materials (mol/J) \\
\hline Without $\mathrm{Na}_{2} \mathrm{MoO}_{4}$ & $\begin{array}{c}(1.1 \pm 0,1) \cdot 10^{-8} \\
\text { With } \mathrm{Na}_{2} \mathrm{MoO}_{4}\end{array}$ \\
\hline & $\begin{array}{c}(0.9 \pm 0,2) \cdot 10^{-8} \\
\text { (average of 7 measurements on distinct samples) }\end{array}$ \\
\hline With $\mathrm{CaMoO}_{4}$ & $\begin{array}{c}(1.3 \pm 0,2) .10^{-8} \\
\text { (average of 6 measurements on distinct samples) }\end{array}$ \\
\hline
\end{tabular}

Contrary to molybdate, the influence of nitrate on the hydrogen production is very significant. Indeed, a drop of a factor 6 is observed Table 5 in the presence of sodium nitrate. Notice that the results of Table 5 are not express in terms of radiolysis yields because results on $\mathrm{NaNO}_{3}$ containing 
materials have been obtained to a single dose of $510 \mathrm{kGy}$ (the linearity of $\mathrm{O}_{2}$ and $\mathrm{H}_{2}$ productions versus dose have thus not been checked in this case). With the same $\mathrm{NaNO}_{3} / \mathrm{H}_{2} \mathrm{O}$ ratio of 0.065 $\left(\left[\mathrm{NO}_{3}\right]=0.8 \mathrm{~mol}^{-\mathrm{L}^{-1}}\right)$, the drop of $\mathrm{H}_{2}$ production is weaker in bulk water (about a factor 3 ) according to [22] than in cement. However, this effect goes along with a significant production of $\mathrm{O}_{2}$ which is equivalent of the production of $\mathrm{H}_{2}$ without $\mathrm{NaNO}_{3}$ (Table 5). This production of $\mathrm{O}_{2}$ is known to come from the direct radiolysis of nitrate ions $[26,27,28]$ as proposed in Equation 2 and Equation 3 :

$\mathrm{NO}_{3}^{-}{ }^{-} m \mathrm{NO}_{3}^{-*} \rightarrow \mathrm{NO}_{2}^{-}+\mathrm{O}$

Equation 2

$\mathrm{NO}_{3}^{-}+\mathrm{O} \rightarrow \mathrm{NO}_{2}^{-}+\mathrm{O}_{2}$

Equation 3

Other reactions expected in the presence of nitrate ions in aqueous solution lead to the formation of nitrite [29]:

$e_{a q}^{-}+\mathrm{NO}_{3}^{-} \rightarrow \mathrm{NO}_{3}{ }^{2-}$

Equation 4

$\mathrm{NO}_{3}{ }^{2-}+\mathrm{H}_{2} \mathrm{O} \rightarrow \mathrm{NO}_{2}{ }^{\circ}+2 \mathrm{OH}^{-}$

Equation 5

$\mathrm{NO}_{2}{ }^{\bullet}+\mathrm{NO}_{2}{ }^{\bullet} \leftrightarrow \mathrm{N}_{2} \mathrm{O}_{4}$

Equation 6

$\mathrm{N}_{2} \mathrm{O}_{4}+\mathrm{H}_{2} \mathrm{O} \leftrightarrow \mathrm{NO}_{3}{ }^{-}+\mathrm{NO}_{2}{ }^{-}+2 \mathrm{H}^{+}$

Equation 7

The concomitant production of $\mathrm{O}_{2}$ and $\mathrm{H}_{2}$ could still raise concerns of safety considering the risk of explosion in nuclear waste storage. Moreover, the global production of radiolytic gas remains unchanged which is not positive towards the risk of over-pressurization and cracking of the materials $[3,4]$. As a consequence, the addition of nitrates to Portland based materials may not be the best solution to manage the concern of radiolytic gas production of cemented waste.

Table 5. Influence of $\mathrm{NaNO}_{3}$ on radiolytic gas production $\left(\mathrm{H}_{2}\right.$ and $\left.\mathrm{O}_{2}\right)$ of $\mathrm{C}_{3} \mathrm{~A}$ free Portland cement pastes (Water/Cement $=0.4$ ). Absorbed doses of $510 \mathrm{kGy}$ and rate dose of $900 \mathrm{~Gy} \cdot \mathrm{h}^{-1} .2 \%$ mass $\mathrm{NO}_{3} / \mathrm{cement}$.

\begin{tabular}{|c|c|c|}
\hline & $\mathrm{N}\left(\mathrm{H}_{2}\right)(\mathrm{mol} / \mathrm{kg}$ of materials) & $\mathrm{N}\left(\mathrm{O}_{2}\right)$ (mol $/ \mathrm{kg}$ of materials) \\
\hline Without $\mathrm{NaNO}_{3}$ & $\begin{array}{c}(5.0 \pm 0.7) \cdot 10^{-3} \\
\text { (average of } 10 \text { measurements on } \\
\text { distinct samples) }\end{array}$ & Not significant \\
\hline With $\mathrm{NaNO}_{3}$ & $(8.5 \pm 0.8) \cdot 10^{-4}$ & $(4.6 \pm 0.5) \cdot 10^{-3}$ \\
\hline With $\mathrm{NaNO}_{3}$ (duplicate) & $(7.8 \pm 0.8) \cdot 10^{-4}$ & $(4.5 \cdot \pm 0.5) \cdot 10^{-3}$ \\
\hline
\end{tabular}

Nitrites are also known to reduce the production of radiolytic hydrogen of bulk water [22]. Thus, its dissolution in the mixing water of Portland based cement paste has been tested to reduce hydrogen 
production. The results of gas analysis after irradiation of such a cement paste of Portland containing $3 \%$ mass of $\mathrm{NaNO}_{2} /$ cement $\left(2 \% \mathrm{NO}_{2}{ }^{-}\right)$are presented in Table 6 . The production of hydrogen decreases significantly but less than with the same amount of nitrate (Table 5). It is also noteworthy that there is almost no production of $\mathrm{O}_{2}$ whereas $\mathrm{N}_{2} \mathrm{O}$ and $\mathrm{NO}$ productions are strong in comparison of $\mathrm{H}_{2}$.

On the whole, the production of radiolytic gas is stronger with $\mathrm{NaNO}_{2}$ than without. This makes this addition poorly attractive even though the production of $\mathrm{H}_{2}$ is lowered without production of $\mathrm{O}_{2}$. The presence of $\mathrm{N}_{2} \mathrm{O}$ and $\mathrm{NO}$ is related to the presence of sodium nitrite in the material and reveals its consumption under irradiation. The probable reactions conducting to nitrous oxide and nitric oxide are presented from Equation 8 to Equation 11:

$$
\begin{aligned}
& \mathrm{H}^{\circ}+\mathrm{NO}_{2}^{-} \rightarrow \mathrm{NO}+\mathrm{OH}^{-} \\
& \mathrm{NO}+\mathrm{NO} \rightarrow \mathrm{N}_{2} \mathrm{O}+\mathrm{O}^{\circ} \\
& \mathrm{N}_{2}+\mathrm{O}^{\circ} \rightarrow \mathrm{N}_{2} \mathrm{O} \\
& \mathrm{N}_{2}+{ }^{\circ} \mathrm{OH} \rightarrow \mathrm{N}_{2} \mathrm{O}+\mathrm{H}^{\circ}
\end{aligned}
$$

Equation 8

Equation 9

Equation 10

Equation 11

Table 6. Influence of $\mathrm{NaNO}_{2}$ on radiolytic gas production of free $\mathrm{C}_{3} \mathrm{~A}$ Portland cement pastes (Water/Cement $=0.4$ ). Dose of $356 \mathrm{kGy}$ at $900 \mathrm{~Gy} \cdot \mathrm{h}^{-1} .2 \%$ mass $\mathrm{NO}_{2}{ }^{-1} /$ cement.

\begin{tabular}{|c|c|c|c|c|}
\hline & \multicolumn{4}{|c|}{ Gas (mol/kg of cement paste) } \\
\hline & $\mathrm{N}\left(\mathrm{H}_{2}\right)$ & $\mathrm{N}\left(\mathrm{O}_{2}\right)$ & $\mathrm{N}\left(\mathrm{N}_{2} \mathrm{O}\right)$ & $\mathrm{N}(\mathrm{NO})$ \\
\hline Without $\mathrm{NaNO}_{2}$ & $(3.6 \pm 0.4) \cdot 10^{-3}$ & $<10^{-5}$ & Not significant & Not significant \\
\hline With $\mathrm{NaNO}_{2}$ & $(1.6 \pm 0.4) \cdot 10^{-3}$ & $3.7 .10^{-5}$ & $(3.8 \pm 0.4) .10^{-3}$ & $(2.3 \pm 0.4) .10^{-3}$ \\
\hline
\end{tabular}

\section{Irradiation of sulfo-aluminate based materials}

Recent development of sulfo-aluminate cements makes them industrially available in Europe for a large range of application including waste conditioning [30]. It is thus interesting to test the sensibility of such cements towards radiolytic gas production. Sulfo-aluminate clinkers contain mostly ye'elimite $\left(C_{4} A_{3} \$\right)$ and dicalcium silicate $\left(C_{2} S\right)$. Hydration of such clinker produces hydrates markedly different of Portland: mainly monosulfo-calcium aluminate $\left(\mathrm{C}_{3} \mathrm{~A} . \mathrm{C} \$ \mathrm{H}_{12}\right)$ and aluminium hydroxide $\left(\mathrm{AH}_{3}\right)$ according to Equation 12. Hydration of $\mathrm{C}_{2} \mathrm{~S}$ in the presence of $\mathrm{AH}_{3}$ leads to silicate hydrogrenat (Equation 13) or strätlingite (Equation 14). Without gypsum, the chemical demand of water for such clinker is around $40-45 \%$ mass. 
In the presence of gypsum (C\$), ye'elimite hydrates in ettringite according to Equation 15:

$\mathrm{C}_{4} \mathrm{~A}_{3} \$+2 \mathrm{C} \$+38 \mathrm{H} \rightarrow \mathrm{C}_{3} \mathrm{~A} .3 \mathrm{C} \$ . \mathrm{H}_{32}+2 \mathrm{AH}_{3}$

The Alpenat clinker provided by Vicat has been compared to the KTS clinker provided by Bellitex. The main difference between these two sulfo-aluminate clinkers is the higher amount of ye' elimite in the Bellitex and thus a lesser amount of $\mathrm{C}_{2} \mathrm{~S}$.

Table 7 Compositions of the two sulfo-aluminate clinkers tested according to supplier's data (\%mass of clinker).

\begin{tabular}{|c|c|c|}
\hline & Alpenat CK (Vicat) & KTS 100 (Bellitex) \\
\hline $\mathrm{C}_{4} \mathrm{~A} 3 \$$ & 54.3 & 71 \\
\hline $\mathrm{C}_{2} \mathrm{~S}$ & $\begin{array}{c}20.8\left(\mathrm{C}_{2} \mathrm{~S} \beta\right) \\
8.3\left(\mathrm{C}_{2} \mathrm{~S} \alpha^{\prime} \text { high }\right)\end{array}$ & 16 \\
\hline $\mathrm{C}_{3} \mathrm{FT}$ & 9.3 & 6.6 \\
\hline $\mathrm{C}_{12} \mathrm{~A}_{7}$ & & 3.1 \\
\hline $\mathrm{C}_{3} \mathrm{MS}_{2}$ & 4.5 & \\
\hline $\mathrm{C}_{6} \mathrm{AF}_{2}$ & 1.2 & \\
\hline periclase (MgO) & & 2.6 \\
\hline$C \$$ & 0.4 & 0.5 \\
\hline Quartz & 0 & 0.5 \\
\hline $\mathrm{Y}-\mathrm{Fe}_{2} \mathrm{O}_{3}$ & 1 & \\
\hline Free $\mathrm{CaO}$ & 0.2 & \\
\hline
\end{tabular}

Gamma irradiations have been performed on pastes prepared with Alpenat clinker using water/clinker ratios of $0.2,0.3,0.4,0.5$ and 0.6 whereas KTS clinker has only be tested at 
water/clinker of 0.6 (exploitation of experiments performed a few years ago). Sulfo-aluminate clinkers have been tested alone or mixed with calcium sulfate to form ettringitic binder.

Radiolysis yields are presented in Figure 5. Several points can be underlined. The first is that sulfoaluminate clinkers with or without gypsum produce as much hydrogen as Portland cement. The higher chemical demand of sulfo-aluminate compared to Portland do not change significantly this property. The different hydrates of Portland and sulfoaluminate seem to have the same sensitivity with respect to $\mathrm{H}_{2}$ production under gamma radiolysis. Another significant point is that the addition of calcium sulfate to sulfo-aluminate clinkers tends to increase slightly the production of hydrogen of both sulfo-aluminate clinkers, suggesting that water bound in ettringite is a little more sensitive to radiolysis compared to water bound in mono-sulfo aluminate. This hypothesis is strengthened by recent results of gamma irradiation on synthetic ettringite: $\mathrm{G}\left(\mathrm{H}_{2}\right)$ of water in this hydrate would be equal to $(7.0 \pm 0.1) \times 10^{-8} \mathrm{~mol} / \mathrm{J}[8]$ which is significantly higher than the yield of $\mathrm{H}_{2}$ of bulk water.

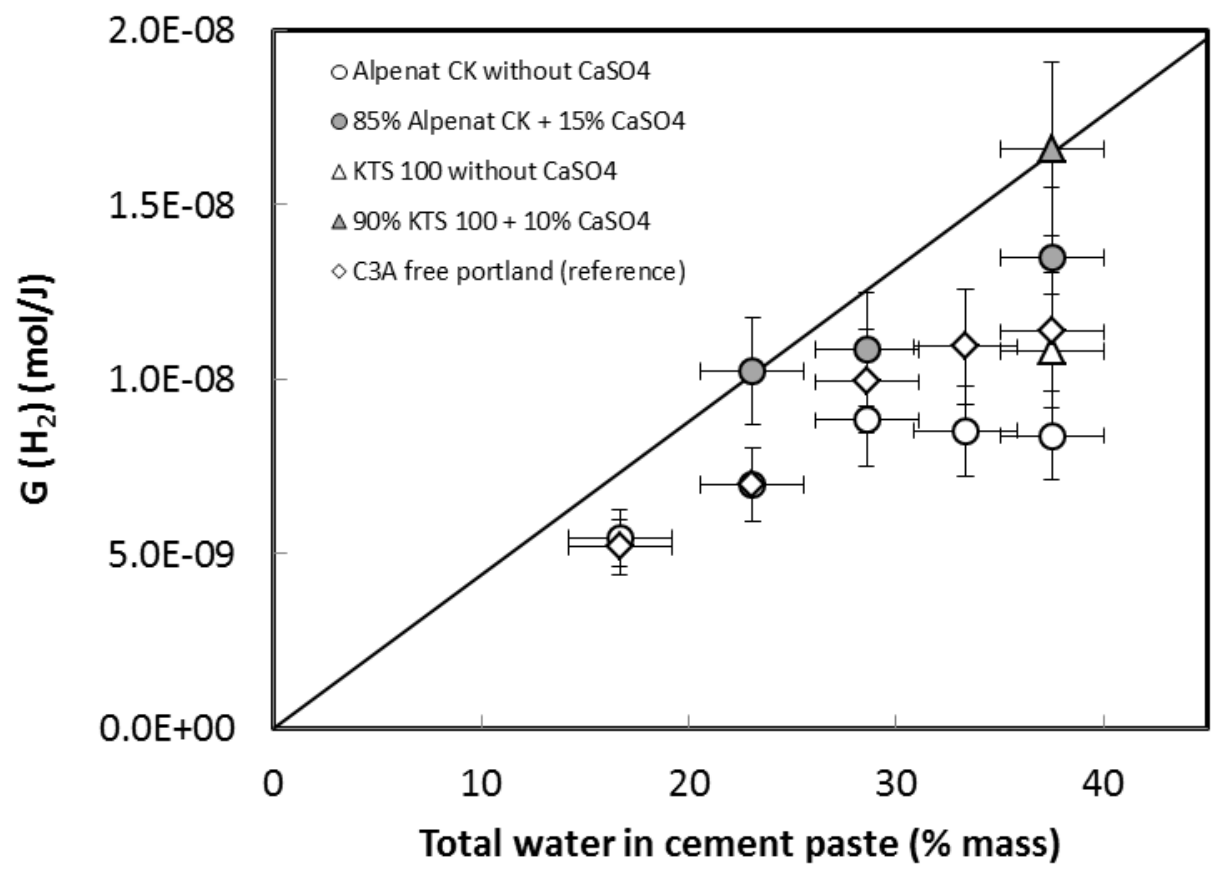

Figure 5. Radiolytic hydrogen yields of sulfo-aluminate cement pastes as a function of their total amount of water. Absorbed dose of $500 \mathrm{kGy}$ at $900 \mathrm{~Gy} \cdot \mathrm{h}^{-1}$. Uninterrupted line: yield according to Equation1

In the same way as Portland cement, the effect of superplasticizer on radiolytic hydrogen production has been assessed with Alpenat CK with or without addition of calcium sulfate. Dosages of SP have been set to obtain fluid but stable pastes and are thus different for each SP : $0.032 \%$ mass of dry matter/cement for MasterEase 3000 and 0.395\%mass of dry matter/cement for MasterRheobuild 
1000. Results of gamma irradiation presented Figure 6 show that there is no major influence of the SP tested on the production of hydrogen of Portland cement pastes. Same results were obtained with Alpenat CK plus calcium sulfate (Figure 6). In this latter case, only MasterEase 3000 has been tested ( $0.035 \%$ mass of dry matter/cement). So, the superplasticizers tested could be used to compensate the deleterious effect of water reduction on workability of fresh cement materials with no concern on radiolytic production of $\mathrm{H}_{2}$.

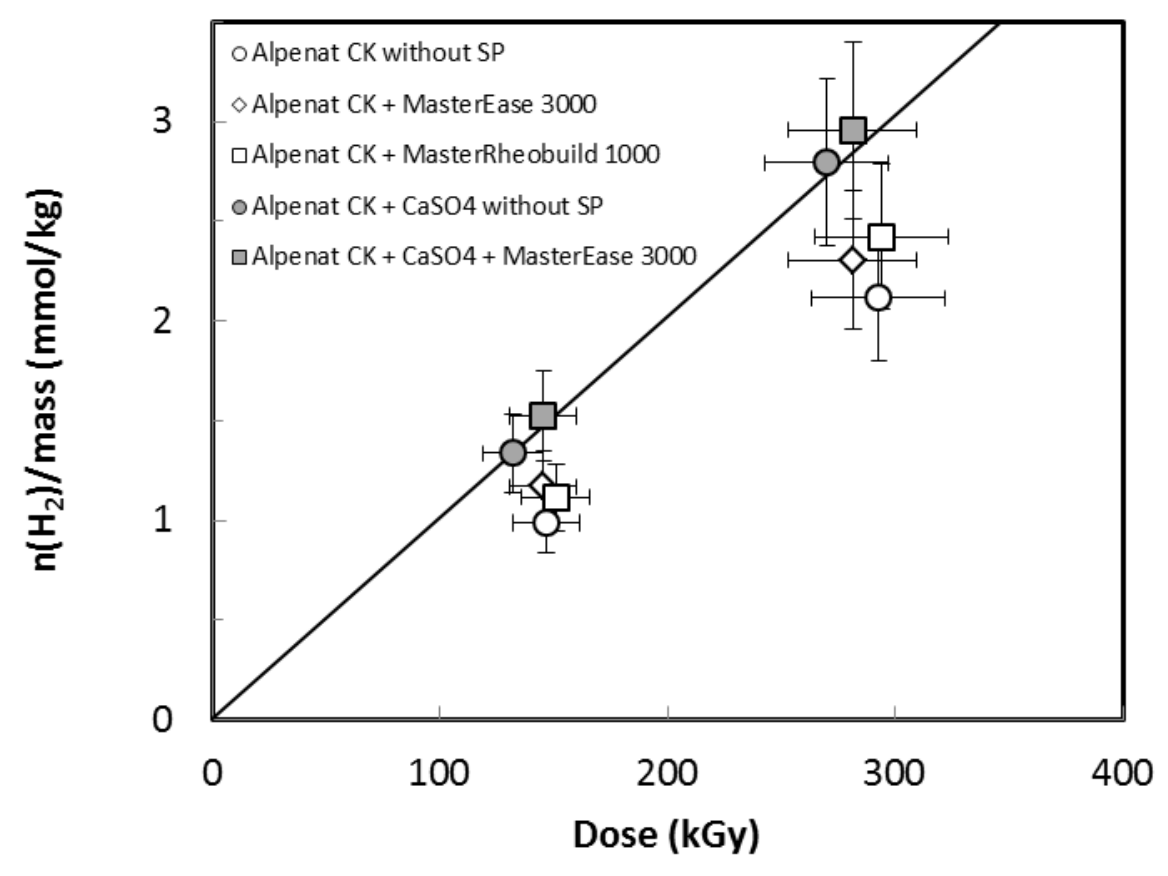

Figure 6. Influence of superplasticizer on radiolytic $\mathrm{H}_{2}$ production of sulfo-aluminate clinker Alpenat-CK without or with calcium sulfate ( $85 \%$ Alpenat $\left.\mathrm{CK}+15 \% \mathrm{CaSO}_{4}\right)$. Water/cement $=0.3$ in mass. Dose rate of $900 \mathrm{~Gy}^{-1} \mathrm{~h}^{-1}$. Uninterrupted line: yield according to Equation1.

The effects of various mineral additions on $\mathrm{H}_{2}$ production of Alpenat CK pastes have also been assessed in the same way as for Portland cement. Synthetic results presented in Table 8 show no significant differences between sulfo-aluminate and Portland cement in relation to the effect of mineral additions. 
Table 8. Influence of mineral additions on radiolytic $\mathrm{H}_{2}$ production of Alpenat $\mathrm{CK}$ cement paste (Water/Cement $=0.4$ )

\begin{tabular}{|c|c|}
\hline Addition & Effect on radiolytic gas production \\
\hline With flying ashes (Carling) & \multirow{3}{*}{ No significant effect on $\mathrm{H}_{2}$ production } \\
\hline With flying ashes (Cordemais) & \\
\hline With $\mathrm{CaCO}_{3}$ filler (Betocarb HP Sassenage) & \\
\hline $\mathrm{Na}_{2} \mathrm{MoO}_{4}$ & \multirow{2}{*}{$\begin{array}{l}\text { No significant effect on } \mathrm{H}_{2} \text { production (Alpenat } \mathrm{CK} \\
\text { with or without } \mathrm{CaSO}_{4} \text { ) }\end{array}$} \\
\hline $\mathrm{CaMoO}_{4}$ & \\
\hline $\mathrm{NaNO}_{3}$ & $\begin{array}{l}\text { Strong reduction of } \mathrm{H}_{2} \text { but strong production of } \mathrm{O}_{2} \\
\text { (similar to Portland cement, Table 5) }\end{array}$ \\
\hline $\mathrm{NaNO}_{2}$ & $\begin{array}{l}\text { Moderate reduction of } \mathrm{H}_{2} \text { but strong production of } \\
\mathrm{N}_{2} \mathrm{O} \text { and } \mathrm{NO} \text { (similar to Portland cement, Table } 6 \text { ) }\end{array}$ \\
\hline
\end{tabular}




\section{Conclusion}

Based on gamma irradiations with a ${ }^{60} \mathrm{Co}$ source, the results obtained in the present work demonstrate that the Ultimat cement (Portland SRO type, free of $\mathrm{C}_{3} \mathrm{~A}$ and $\mathrm{CaSO}_{4}$ ) releases as much hydrogen as an ordinary Portland whereas the white Portland releases significantly more. Sulfoaluminate clinkers tested release nearly as much hydrogen as the SRO and ordinary Portland and the addition of calcium sulfate to sulfo-aluminate clinkers increases moderately this production of hydrogen. Besides, mineral additions such as flying ashes, limestone or siliceous fillers have no significant influence on hydrogen production of such cement materials.

The influence of water content (in the range of 15 to $40 \%$ mass) in cement pastes of Portland and sulfo-aluminate indicates that the status of water (free water of porosity or bound in cement hydrates) has no major influence on its production of $\mathrm{H}_{2}$ under gamma irradiation. For such cement materials, the yield of production of hydrogen can be estimated considering the radiolytic yield of bulk water $\left(4.4 .10^{-8} \mathrm{~mol} / \mathrm{J}\right)$ and its mass fraction in the material: $\mathrm{G}\left(\mathrm{H}_{2}\right)_{\text {material }}=\mathrm{G}\left(\mathrm{H}_{2}\right)_{\text {bulk water }} \times$ mass fraction of total water of material). As a consequence, it is possible to reduce the radiolytic production of hydrogen of such cements based materials by reducing the amount of total water in the materials during its preparation. Nevertheless, a tremendous drop of hydrogen production cannot be reach because rheological constraints to mix the components do not allow a huge reduction of water, even with efficient superplasticizers, which allow a typical drop of water of a factor 2. It has also been checked that a selection of superplasticizers has no significant influence on hydrogen production of Portland and sulfo-aluminate cement pastes.

Another way to reduce hydrogen production of cement materials is to add products known to reduce the hydrogen production of aqueous solution under irradiation. Such products $\left(\mathrm{MoO}_{4}{ }^{2-}, \mathrm{NO}_{3}{ }^{-}\right.$and $\mathrm{NO}_{2}^{-}$) known as radical scavengers have been added in the mixing water of Portland and sulfoaluminate cements. In the case of molybdenum, the effect on $\mathrm{H}_{2}$ production is not really significant because of a probable precipitation of $\mathrm{MoO}_{4}{ }^{2-}$ in very stable $\mathrm{CaMoO}_{4}$ during hydration of the cement. With nitrate and nitrite, the effects on $\mathrm{H}_{2}$ production are more significant but the noticeable production of other radiolytic gas like $\mathrm{O}_{2}, \mathrm{NO}$ or $\mathrm{N}_{2} \mathrm{O}$ makes these products poorly attractive considering the risks of cracking by internal overpressure in the materials. The identification of a product able to reduce drastically and lastingly $\mathrm{H}_{2}$ production of cement materials without other gas release would be of great interest to condition intermediate level nuclear waste. Moreover, the efficiency of such product should be demonstrated towards alpha emitters which are often present in such wastes. 


\section{Acknowledgments}

Project supported by Andra under the "Investing in the Future programme" ("Investissement d'Avenir") - Selected under the Andra Call for Projects "Optimization of post-dismantling radioactive waste management".

The authors are grateful to M. Cornaton and D. Durand, for their contribution to gas mass spectrometry analysis.

\section{Data availability}

The raw/processed data required to reproduce these findings cannot be shared at this time as the data also forms part of an ongoing study

\section{References}

[1] AIEA, " Retrival and conditioning of solid radioactive waste from old facilities» TECHNICAL REPORTS SERIES No. 456 (2007).

[2] N.E. Bibler, "Radiolytic gas production from concrete containing Savannah River Plant waste", Rapport DP-1464, Savannah River Laboratory (1978)

[3] C. J. Kertesz, P. R. Chenavas, L. Auffret, « Conditionnement de cendres d'incinérateur alpha et bêta gamma, obtenues par incinération des déchets radioactifs, par enrobage, dans différentes matrices », Report EUR 14365 FR (1993) Commission européenne, Sciences et techniques nucléaires

[4] C. Madic, G. Koehly, « Comportement à long termes des matrices d'enrobage contaminées en émetteurs alpha ; Etude du phénomène de rupture d'éprouvettes constituées de liants hydrauliques contaminés en plutonium 238 et curium 244 au cours de leur lixiviation » Report C.E.A. DGR 134 (1986).

[5] J. Baron, "La durabilité des bétons », Presses de l'Ecole nationale des ponts et chaussées, 1996 (ISBN-10: 2859781846) p 64.

[6] P. Bouniol, E. Bjergbakke, "A comprehensive model to describe radiolytic processes in cement medium ", Journal of Nuclear Materials 372 (2008) 1-15.

[7] P. Bouniol, « Etat des connaissances sur la radiolyse de l'eau dans les colis de déchets cimentés et son approche par simulation », Report CEA-R-6069 (2004). ISSN 0429 - 3460.

[8] L. Acher, " Investigation of the behaviour of cement matrices and their hydrates under $\gamma$ and electron irradiation » Ph.D. Thesis of University Paris-Saclay (2017).

[9] J. Kaddissy, « Hydrogen production from irradiated aluminum hydroxide and oxyhydroxide » Ph.D. Thesis of University Paris-Saclay (2016).

[10] F. Vodàk, K. Trtik, V. Sopko, O. Kapickova, P. Demo, « Effect of g-irradiation on strength of concrete for nuclear-safety structures », Cement and Concrete Research 35, 1447-1451, (2007).

[11] M. Robira, B. Hilloulin, A. Loukili, G. Potin, X. Bourbon, A. Abdelouas, « Multi-scale investigation of the effect of gamma irradiations on the mechanical properties of cementitious materials », Construction and Building Materials 186 (2018) 484-494.

[12] J. Pachner, «Assessment and management of ageing of major nuclear power plant components important to safety: Concrete containment buildings » IAEA-TECDOC-1025, IAEA, Vienna, (1998)

[13] T.M. Rosseel, «Review of the curent state of knowledge on the effects of radiation on concrete » Journal of advanced concrete technology, 14, 368-383 (2016).

[14] https://icic2017.ornl.gov/

[15] http://www.harwell-dosimeters.co.uk/perspex/

[16] ISO-ASTM 51261 Guide for selection and calibration of dosimetry systems for radiation processing.

[17] J. Baro, J. Sempau, J.M. Fernandez-Varea, and F. Salvat, Nuclear Instruments and Methods in Physics Research, Sect. B 100;31 (1995).

[18] M. Ferry, A. Dannoux-Papin, N. Dély, S. Legand, D. Durand, J.L. Roujou, C. Lamouroux, V. Dauvois, P. Coignet, F. Cochin, S. Esnouf, « Chemical composition effects of methylene containing polymers on gas emission under gamma-irradiation », Nuclear Instruments and Methods in Physics Research B 334 (2014) 6976. 
[19] T.C. Powers, " Some aspects of the hydration of Portland cement », J. Port. Cem. Assos. Res. Dev. Lab. 3, (1961) 47-56.

[20] P. Stutzman, A. Heckert, A.Tebbe, S. Leigh, « Uncertainty in Bogue-calculated phase composition of hydraulic cements ", Cement and Concrete Research 61-62 (2014) 40-48.

[21] J.A. LaVerne, M.R. Ryan, T. Mu. "Hydrogen production in the radiolysis of bromide solutions" Radiation Physics and Chemistry 78 (2009) 1148-1152.

[22] B. Pastina, J.A. LaVerne, S.M. Pimblott, «Dependence of molecular hydrogen formation in water on scavengers of the precursor to the hydrated electron". J.Phys. Chem. A 103 (1999), 5841-5846.

[23] J. Baron, " La durabilité des bétons », Presses de l'Ecole nationale des ponts et chaussées, 1996 (ISBN-10: 2859781846) p 64.

[24] P. Bouniol, B. Muzeau, V. Dauvois, « Experimental evidence of the influence of iron on pore water radiolysis in cement-based materials », Journal of Nuclear Materials 437 (2013) 208-215.

[25] A. Kindness, E.E. Lachowski, A.K. Minocha, F.P. Glasser, "Immobilisation and fixation of molybdenum (VI) by Portland cement", Waste Management, Volume 14, Issue 2, (1994), Pages 97-102.

[26] M. L. Hyder, "The Radiolysis of Aqueous Nitrate Solutions », The Journal of Physical Chemistry, Volume 69, Number 6 June 1966.

[27] H. Bernhard Pogge, F. T. Jones, " The Effects of Temperature and Additives in the Radiolysis of Potassium Nitrate », The Journal of Physical Chemistry, Volume 74, Number 8 April 18, (1970), 1700-1705.

[28] P.Y. Jiang " Gamma radiolysis study of concentrated nitric acid solutions », J. Chem. Soc. Faraday Trans., 90 (1994), pp. 93-95.

[29] M. Daniels, E. E. Wigg, « Radiation Chemistry of the Aqueous Nitrate System. I. y Radiolysis of Dilute Solutions ", The Journal of Physical Chemistry, Volume 71, Number 4 March (1967)

[30] J-B, Champenois, M. Dhoury, C. Cau Dit Coumes, C. Mercier, B.Revel, P. Le Bescop, D.Damidot, « Influence of sodium borate on the early age hydration of calcium sulfoaluminate cement " Cement and Concrete Research 70 (2015) 83-93. 